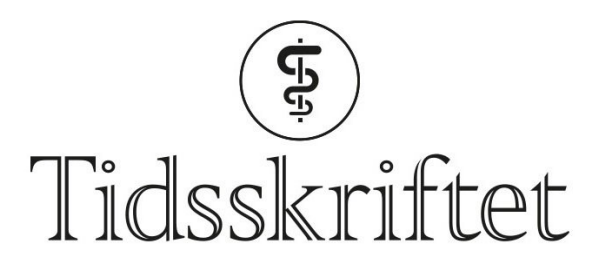

DEN NORSKE LEGEFORENING

\title{
Er gentamicin mindre ototoksisk enn antatt?
}

FRA ANDRE TIDSSKRIFTER

SOFIE PAUS

Tidsskriftet

En norsk studie viste ingen hørselsskader hos barn i skolealder som var blitt behandlet med gentamicin som nyfødte.

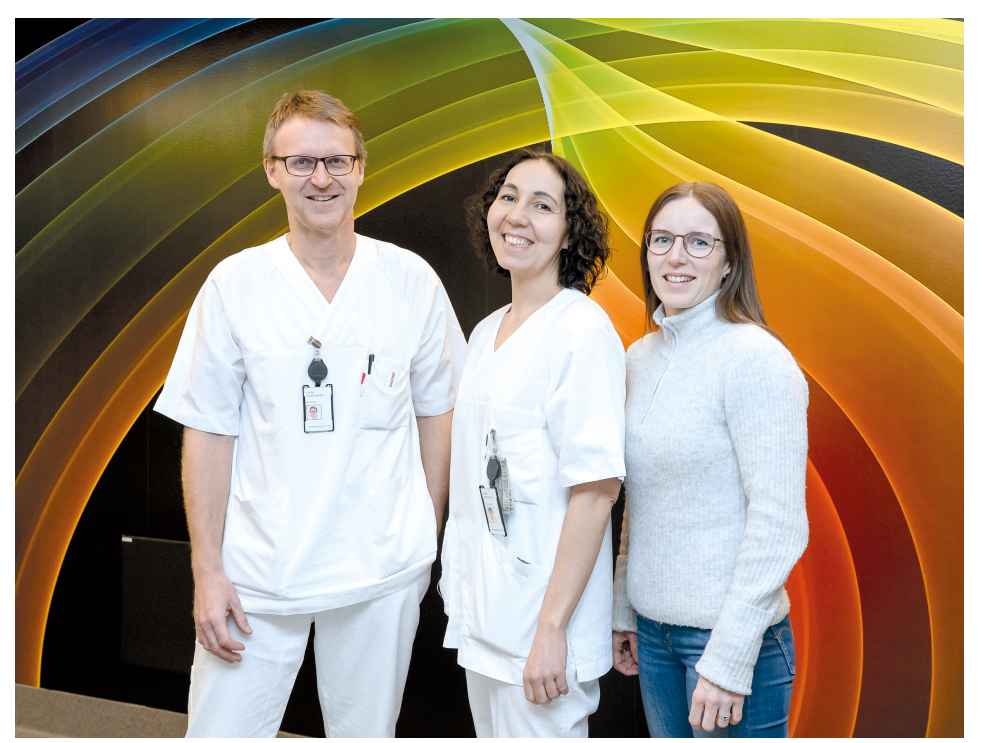

Fra venstre: Claus Klingenberg (barnelege), Dagny Hemmingsen (øre-nese-hals-lege), Camilla Mikalsen (audiograf). Foto: Per-Christian Johansen, Universitetssykehuset Nord-Norge.

Forskere ved Universitetssykehuset Nord-Norge har undersøkt langtidseffekter av gentamicin på hørsel hos skolebarn som fikk legemiddelet i nyfødtperioden (1). De fulgte en kohort med nyfødte som hadde mottatt gentamicin i høy dose $(6 \mathrm{mg} / \mathrm{kg})$ i perioden 2004-12. 219 gentamicineksponerte barn og 33 friske barn ble testet med audiometriske målinger, og resultatene ble analysert basert på grad av gentamicineksponering og konfunderende faktorer, som fødselsvekt og mellomøresykdom. Det var ingen forskjeller mellom gruppene hva gjaldt høreterskel, heller ikke for høyere frekvenser som antas å være det mest sensitive området for ototoksisk hørselstap.

- Det har vært mye bekymring rundt mulig ototoksisk effekt av gentamicin hos nyfødte, men i denne studien fant vi ingen holdepunkter for å bekrefte den effekten, sier Claus Klingenberg. Han er overlege og professor i barnesykdommer og studiens sisteforfatter. Han mener det er viktig å undersøke sikkerhet ved medikamentell behandling gitt til 
nyfødte, spesielt medisiner som brukes så hyppig som gentamicin. Gentamicin er i dag en del av standardbehandling mot sepsis, også for nyfødte.

- Tilstrekkelig høye serumkonsentrasjoner er nødvendig for effekt. Det kjent at høye konsentrasjoner av aminoglykosider kan ha en ototoksisk virkning. Imidlertid har det manglet gode data på ototoksisitet hos nyfødte, sier Klingenberg.

Artikkelen er den første publikasjonen i doktorgradsprosjektet til førsteforfatter Dagny Hemmingsen. Prosjektet er et samarbeid mellom Barneavdelingen og Øre-nese-halsavdelingen ved Universitetssykehuset Nord-Norge.

\section{LITTERATUR:}

1. Hemmingsen D, Mikalsen C, Hansen AR et al. Hearing in schoolchildren after neonatal exposure to a high-dose gentamicin regimen. Pediatrics 2020; 145: e20192373. [PubMed][CrossRef]

Publisert: 22. mai 2020. Tidsskr Nor Legeforen. DOI:10.4045/tidsskr.20.0168

(C) Tidsskrift for Den norske legeforening 2020. Lastet ned fra tidsskriftet.no 